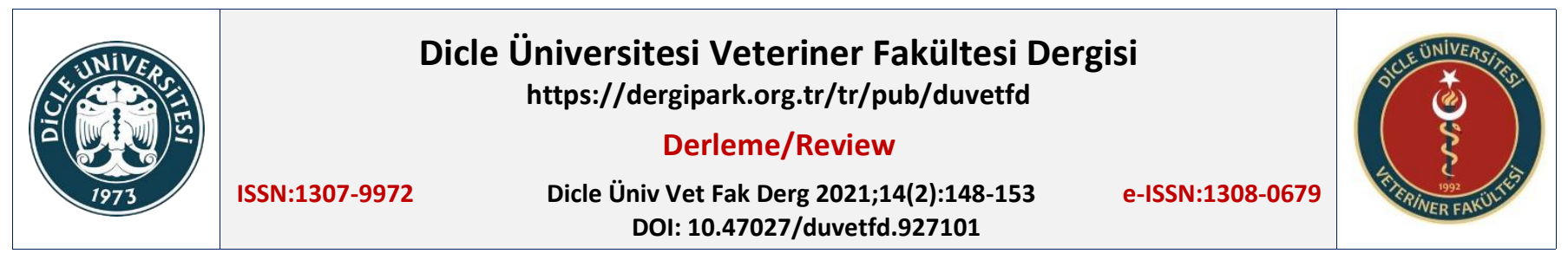

\title{
Süt Sığırlarında Tırnak Kesimi: Ayak Sağlığı ve Topallığa Etkisi Üzerine Bir Değerlendirme
}

\author{
Celal iZCi1,a , Kadir SULU ${ }^{1, b, \bowtie}$ \\ ${ }^{1}$ Selçuk Üniversitesi, Veteriner Fakültesi, Cerrahi AnabilimDalı, Konya, TÜRKiYE \\ aORCID: 0000-0003-0207-4575; bORCID: 0000-0002-7246-8185
}

\begin{tabular}{ccc}
\hline Geliş Tarihi/Received & Kabul Tarihi/Accepted & Yayın Tarihi/Published \\
24.04 .2021 & 11.06 .2021 & 31.12 .2021 \\
\hline
\end{tabular}

Öz

Tırnak kesimi sığırlarda topallıkların önlenmesinde önemli bir uygulamadır. Bu uygulama; laktasyondaki ineklerde tırnak lezyonu ve topallık oluşumunu azalttığı gibi, ilk doğumunu yapacak düvelerde de boynuz tırnak lezyonlarına karşı koruyucu bir etki sağlar. Ayak ve tırnak sağ lığının sürekliliği, düzenli ve doğru yapılan tırnak kesimi ile mümkündür. Bu bağlamada, etkili tırnak kesiminin yapııdığı çiftliklerde topallıkların \%25 azaldığı, uygun zamanda yapılan tırnak kesiminin topallık insidansını \%50 azalttığı bildirilmiştir. Düzenli ve doğru yapılan tırnak kesimi iki önemli fayda sağlar. Birincisi; topalığa neden olabilecek lezyonlar erken safhada belirlenmiş olur. íkincisi; her bir tırnağın kendi içinde ve iki tırnak arasındaki yük dağılım dengesini sağlar ve böylece lezyon oluşumunu önler. Hatalı tırnak kesimi dünyada ve ülkemizde süt sığırlarında topallığa neden olan en önemli faktörlerden birisidir. Tırnak kesimi normal bir tırnağın morfolojik ve biçimsel özellikleri dikkate alınarak yapılır. Tırnaklarda uzamaya bağlı oluşan biçimsel değişiklikler her tırnak ve hayvan için özeldir. Uzamış ve biçimsel değişikliğe uğramış tırnak normal özelliklerinin birçoğunu kaybeder. Bu nedenle tırnak kesimi alışılagelenin aksine mutlaka bu konuda eğitim almış profesyonel kişiler tarafından yapılmalıdır. Bu derlemenin amacı, sığırlarda uygulanan tırnak kesim yöntemleri ve bu yöntemlerin ayak sağlığı üzerindeki etkilerini değerlendirmektir.

Anahtar Kelimeler: İnek, tırnak kesimi, tırnak sağlığı, topallık

Hoof Trimming in Dairy Cattle: An Evaluation on Its Effect on Foot Health and Lameness

Abstract

Claw trimming is an important practice in preventing lameness in cattle. This application; It reduces the formation of hoof lesions and lameness in lactating cows and also provides a protective effect against horn lesions in heifers that will give birth for the first time. The sustainability of foot and claw health is possible with regular and correct hoof trimming. In this binding, it has been reported that in farms where effective claw trimming is performed, lameness decreases by $25 \%$, and timely trimming reduces the incidence of lameness by $50 \%$. Regular and correct claw trimming provides two important benefits. Firstly; lesions that may cause lameness are determined at an early stage. Latter; it provides the load distribution balance within each claw and between the hooves and thus prevents the formation of lesions. Incorrect claw trimming is one of the most important factors that cause lameness in dairy cattle in the world and in our country. Trimming is done by considering the morphological and formal features of a normal claw. The formal changes that occur as a result of horn growth are specific for each claw and animal. The elongated and deformed claw loses many of its normal features. For this reason, claw trimming should be done by professional people who have been trained in this subject, contrary to the usual. The purpose of this review is to evaluate the hoof trimming methods used in cattle and the effects of these methods on foot health.

Key Words: Claw health, claw trimming, cow, lameness

\section{GiRiş}

Topallık, süt sığırcılığı çiftliklerindeki en önemli sağıık, verimlilik ve refah sorunlarından biridir. Dünyada modern süt sığırcılığı işletmelerinde topalık prevalansının \%20-36 aralığında olduğu ve bunun ülkeler, bölgeler, çiftlikler ve farklı barınak sistemleri arasında önemli ölçüde değişiklik gösterdiği söylenebilir. Bu farklılık ayak hastalıkları ve tırnak bozukluklarının çok faktörlü doğasından kaynaklanır (1). Topallık, sonuçları itibariyle süt sığırcılığında önemli ekonomik kayıplara neden olur. Sebep olduğu en önemli ekonomik kayıplar arasında; süt verimindeki azalmalar $(2,3,4)$, üreme performansındaki azalmalar (5) ve kesim oranınındaki artışla birlikte hayvanların sürü ömrünün kısalması (6) sayılabilir. Tüm bu birleşenleriyle birlikte topallıklar; süt sığırlarında yaygın olarak görülen diğer klinik hastalıklarla karşılaştırıldığında hayvan başına ve sürü bazında en maliyetli hastalık grubunu oluşturur $(1,7)$. (Tablo 1)

Topallığın süt sığırcılığındaki bu olumsuz etkilerine rağmen, topallığı önleyici uygulamaları değerlendiren araştırma sayısı oldukça sınırıdır. Süt sığırlarında topallığı önlemek ve yönetmek amacıyla en sık önerilen uygulama tırnak kesimidir $(8,9)$. Tırnak kesimi tırnak sağlığını etkiler. Amacı ve fonksiyonu itibariyle tırnak kesimi koruyucu-önleyici (fonksiyonel) ve terapötik olmak üzere iki ana başlıkta incelenebilir. Koruyucu tırnak kesimi tırnağın normal morfolojik özelliklerinin korunması ve özelikle laktasyon dönemindeki topallık insidans ve 
prevalansının azalmasında etkilidir. Koruyucu tırnak kesiminin amacı tırnağın uzamasını önlemek, uzamış tırnağı düzelterek normal fonksiyonlarını yeniden sağlamak ve böylece; her bir tırnağın kendi içinde ve tırnaklar arasındaki yük dağıIım dengesini sağlamak, tırnak bozukluklarını ve hastalıklarını önceden tespit etmek ve önlemektir $(1,10)$. Terapötik tırnak kesimi diğer tedavi uygulamlarıyla birlikte gerek boynuz ve canlı tırnak lezyonları (BCTL) gerekse enfeksiyöz tırnak lezyonlarının tedavisinde etkilidir. Terapötik tırnak kesiminde amaç; canlı doku ile ilişkisi kesilmiş ve gevşemiş nekrotik tırnak dokusunu uzaklaştırmak, hasta tırnağın lezyonlu bölgesinde veya tamamı üzerindeki basıncı azaltarak (Şekil 1) ağrı yönetimini içeren diğer tedavi protokolleri ile birlikte iyileşme sürecine katkı sağlamaktır $(1,11)$.

Tablo 1. Süt Sığırlarında görülen klinik hastalıkların bireysel ve sürü bazında maliyeti (7).

\begin{tabular}{lrr} 
Hastalık & Maliyet/Inek & $\frac{\text { Sürü Maliyeti/Yıl }}{(100 \text { İnek) }}$ \\
\hline Mastitis & $262 \$$ & $10.490 \$$ \\
Abomasum & $489 \$$ & $2.447 \$$ \\
deplasmanı & $325 \$$ & $4.874 \$$ \\
Retensiyo / metritis & $478 \$$ & $14.330 \$$ \\
\hline
\end{tabular}

Şekil 1. Ülser alanındaki gevşemiş ve nekrotik tırnak dokusu uzaklaştırılır ve hasta tırnağın lezyonlu bölgesi üzerindeki basınç azaltılır.

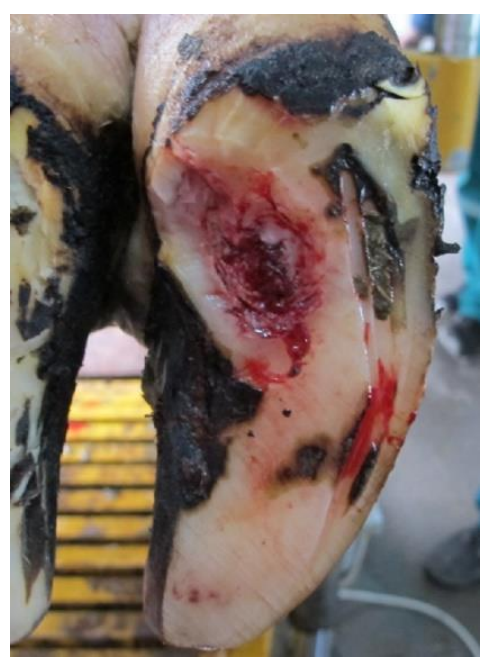

Tırnak kesimi ile çeşitli tırnak lezyonları arasındaki ilişkilerin gözden geçirilmesi, topallık yönetiminde tırnak kesiminin faydalarının anlaşılmasında önemlidir. Bu derlemede; sığırlarda topallık yönetimi için önerilen tırnak kesim yöntemlerinin tırnak sağlığı ve çeşitli tırnak lezyonlarının tedavisindeki etkinliğinin değerlendirilmesi amaçlanmıştır.

\section{Tırnak Kesim Yöntemleri}

Bugün için dünyada tanımlanmış birkaç farklı tırnak kesim yöntemi bilinmektedir. Bunlar; fonksiyonel tırnak kesimi veya Hollanda (Ducth) yöntemi (10), beyaz çizgi yöntemi (12), beyaz çizgi atlas yöntemi (13) ve Kansas yöntemidir (14). Yöntemler arasında önemli benzerlikler olsa da profilaktik veya terapötik amaçlarına göre taban kalınlığı, taban eğimi ve uygulamada ölçülebilir farklılıklar vardır.

Bu yöntemler metakarpal/tarsal kemikler ile taban yüzeyi arasındaki açılanma farkına göre sınıflandırılabilir. Yöntemlerin çoğu $(8,10,12,15,16)$ abaksiyal ve aksiyal tırnak duvarlarının aynı seviyede ve metakarpal/tarsal kemiklerin uzun eksenine dik olacak şekilde kesildiği düz bir tabanı savunur. Fonksiyonel tırnak kesimi ve beyaz çizgi yöntemlerine göre; Holstein ırkı ineklerde ön duvar uzunluğu $7.5 \mathrm{~cm}$ taban ucu kalınlığı ise $6 \mathrm{~mm}$ olmalıdır. Temel ilkeleri E.T. Raven (10) tarafından tanımlanan fonksiyonel tırnak kesimi (Ducth Yöntemi) yöntemi, özel ölçümler yapılarak en uygun dorsal duvar uzunluğunu ve taban ucu kalınlığını elde etmeye odaklanır. Beyaz çizgi yöntemi uygun dorsal duvar uzunluğunu ve taban kalınlığını elde etmek için taban okuma yöntemini esas alırken (12), diğer bir yöntem referans olarak tırnak açısını (15) kullanmayı tercih eder. Fonksiyonel tırnak kesimi ve beyaz çizgi yönteminde taban kalınlığının belirlenmesi, özellikle arka ayak lateral ve medial tırnaklar arasındaki yük dağılımının eşit olması bakımından önemlidir (17). Tırnak tabanının düz kesilmesini öneren yöntemlere alternatif olarak Kansas yöntemi tabanın eğimli kesilmesini önerir. Bu yöntem, tırnağın taban yüzeyinin metakarpus/ metatarsusun uzun eksenini kestiği dik çizginin abaksiyalden aksiyale 3-4 derecelik bir açıyla eğimli olmasını önerir.

Tırnak kesim yöntemlerinin topallık yönetimindeki etkinliği hakkında çok az veri bulunmaktadır. Saha şartlarında tırnak kesimi yapanların büyük çoğunluğu, bu yöntemleri kendi kişiselleştirilmiş tırnak kesme tekniklerinin oluşmasında temel olarak kullanmaktadır. Nitekim 2014 yılında yapılan tırnak kesimi konferansına katılan tırnak kesicilerinin $\% 55$ 'inin fonksiyonel tırnak kesimini, \%7'si beyaz çizgi yöntemini, \%12'sinin Kansas yöntemini ve \%15'inin de kombine yöntem kullandığı belirlenmiştir (18).

\section{Sığırlarda Tırnak Lezyonlarının Sınıflandırılması ve Tanımlanması}

Süt sığırlarında topallıkların \%90'ından fazlası ayak hastalıkları ve tırnak bozukluklarına ilişkin şekillenir $(7,17)$. Süt sığırlarında topallığa neden olan ayak hastalıklarını non-enfeksiyöz nitelikli boynuz tırnak ve canlı tırnak lezyonları (BCTL) ve enfeksiyöz nitelikli ayak derisi hastalıkları olmak üzere iki ana başlıkta incelemek mümkündür $(1,19)$.

\section{Boynuz ve Canlı Tırnak Lezyonları (BCTL) ve Tırnak Kesimi}

BCTL, hem canlı dokuyu hem de tırnağı kapsayan lezyonlar için kullanılan genel bir terimdir. BCTL; tırnak bozuklukları, travma ve laminitisle ilişkili olan hastalıklar olarak tanımlanabilir. Tırnak bozuklukları olarak aşırı uzamış tırnak, tirbüşon tırnak, makasvari tırnak, asimetrik tırnak sayılabilir. Travmatik ve laminitisle ilişkili olan hastalıklar ise beyaz çizgi hastaIığı, taban hemorajisi, taban ülseri, taban ucu lezyonları (ülser, apse, nekroz vb), ökçe ülseri, tırnak çatlakları, interdigital hiperplazi, çift taban ve ince taban gibi lezyonlardan oluşur $(19,20,21)$. Bunlar arasında bugün için dünyada en yaygın görüleni taban ülseri ve beyaz çizgi hastalığıdır $(20,22)$. $\mathrm{Bu}$ hastalıkların oluşumunda, tırnağın asıcı bağ sistemini (suspensory apparatus) zayıflatan ve doğum sürecinde meydana gelen metabolik ve hormonal değişiklikler ve bunlara eşlik eden subakut ruminal asidozis (SARA) gibi metabolik bozukluklar ve laminitis etkili olmaktadır $(23,24)$. Bunların dışında özellikle doğum sonrası negatif enerji dengesizliği (NED) gelişen yüksek verimli ineklerde vücut kondüsyon skorunun (VKS) düşmesi $(17,25)$ ve ökçe yastığının kalınlığının 
azalması $(24,26,27,28,29)$, sert zeminler $(17,30,31)$, tırnağın uzama ve aşınma dengesizlikleri sonucu her bir tırnağın kendi içinde ve tırnaklar arasındaki yük dağııım dengesinin bozulması ve bunun sonucu taban ve ökçe koryumunun yıkımlanmasına neden olan mekanik faktörler (23) BCTL oluşumunda etkili olmaktadır. Bu hastalıkların önlenmesinde koruyucu tırnak kesimi, tedavisinde ise terapötik tırnak kesimi oldukça etkilidir.

\section{Taban Ülseri - Beyaz Çizgi Hastalığı ve Tırnak Kesimi}

Her bir tırnağın kendi içinde ve tırnaklar arası yük dağılım dengesini oluşturmayı esas alan fonksiyonel tırnak kesimi, laktasyon sırasında tabanda kanama, taban ülseri, çift taban ve beyaz çizgi hastalığı oluşum riskini azaltır (15). Koruyucu amaçla tırnak kesimi yapılan çiftliklerde yapılmayanlara göre BCTL insidansının daha düşük (11) olduğu, kuru dönem öncesi yapılan tırnak kesiminin bir sonraki laktasyonda taban ülseri olasılığını azalttığı (32) bildirilmiştir. Bu bağlamda koruyucu tırnak kesiminin BCTL oranının azaltılmasında yararlı olduğu ileri sürülebilir. Birçok BCTL olgusunda enfeksiyon derin dokulara ve hatta tırnak kemiğine kadar yayılır. Bu tür olgularda sadece ilaç tedavisi ile sonuç alınması mümkün değildir (33). Bu tür olguların tedavisinde en önemli uygulama terapötik tırnak kesimidir. BCTL'li ineklerde yapılan terapötik tırnak kesimi, topallayan inek oranında ve topallık skorunda önemli bir azalmaya yol açmıştır $(34,35)$. Terapötik tırnak kesiminde ilk adım, canlı doku ile ilişkisi kesilmiş tüm tırnak dokusunun çıkarılmasıdır (Şekil 2). Bu uygulamayla anaerobik bakterilerin üreme ortamı bozulur ve olası apse oluşumu engellenmiş olur $(36,37,38)$. Bu amaçla tabandaki ülserlerin etrafındaki alan düzeltilir ve tabana aksiyale doğru eğim verilir. Gevşemiş ve nekroze olmuş tırnak dokusu, ülserin çevresinde ince bir tırnak tabakası kalıncaya kadar 45 derecelik açı ile ülserden uzaklaştırılır (Şekil 1). Böylece lezyonlu bölge üzerindeki basınç azaltılmış olur. Bunu yaparken canlı doku mümkün olduğunca korunmalıdır. Beyaz çizgi lezyonlarında abaksiyal olarak eğim verilir ve apse boşluğu açığa çıkıncaya kadar defekt bulunan lateral duvarın taban ve beyaz çizgi ile ilişkili kısmı uzaklaştırılır (Şekil 3) (1, 22). Terapötik tırnak kesiminde ikinci adım, BCTL'ye bağlı ağrıyı gidermek ve uygulanacak tedavinin etkinliğini arttırmak için yük dağılımını hastalıklı tırnağın lehine olacak şekilde ayarlamaktır. Topallığa bağlı oluşan ağrıyı yönetmenin en iyi yolu çoklu (multimodal) ağrı yönetimidir. Bunun için lezyonun şiddetine bağlı olarak ya hasta tırnağın lezyonlu bölgesi ya da hasta tırnağın tüm tabanı yontularak yüksekliği azaltılır (Şekil 1). Böylece lezyonlu bölgenin üzerindeki yük ve basınç kalkar ve ağrı azalır. Ancak birçok durumda bu uygulama ile hasta tırnak üzerindeki yük ve basınç tamamen kaldırılamaz. Bu gibi durumlarda sağlam tırnağa ortopetik takoz uygulaması yapılmalıdır $(1,8$, $10,22,39)$. Ortopedik takoz uygulaması ile birlikte nonsteroid antiinflamatuar (NSAID) ilaç uygulamaları yangıyı azaltarak iyileşmeye yardımcı olur. Terapötik tırnak kesiminin etkinliğinde BCTL'nin türü, şiddeti ve sıklığı önemlidir (40).

\section{Enfeksiyöz Ayak Hastalıkları ve Tırnak Kesimi}

Enfeksiyöz ayak hastalığı olarak digital dermatitis (DD), interdigital dermatitis ID), ökçe erozyonu (ÖE) ve interdigital flegmon-nekrobasillozis (footrot) (IF) sayılabilir. Bunlar arasında bugün için dünyada en yaygın görüleni sırasıyla $D D$ ve IF'dir. Bu hastalıklar genellikle ayak derisini kapsar ve oluşumunda ıslak ve hijyenik olmayan barınak şartları, ayak banyosunun olmaması veya yanlış uygulanması gibi tüm sürüyü etkileyen faktörler etkili olmaktadır (41). Bu hastalıklara bakteriyel mikroorganizmalar neden olmaktadır. DD hem dünyada hem de ülkemizde insidans ve prevalansı yüksek bir ayak derisi hastalığıdır. Yapılan birçok çalışmada $(42,43)$ fonksiyonel tırnak kesimi ve DD prevalansı arasındaki ilişki ortaya konmuştur. Bu ilişki, koruyucu ve terapötik tırnak kesimi bağlamında değerlendirildiğinde, mevcut veriler koruyucu tırnak kesiminin tek başına süt sığırcılığı işletmelerindeki DD prevalansı üzerinde çok az etkisi olduğunu göstermektedir. Kısa aralıklarla koruyucu tırnak kesimi yapılan ineklerde DD prevalansının daha düşük olduğu bildirilmiştir (44). Bu durum sık yapılan tırnak kesiminin DD’nin erken teşhisine imkan sağlaması ile açıklanabilir.

Terapötik tırnak kesiminin DD'den etkilenen ineklerin iyileşmesi üzerinde etkisi olduğu bildirilmiştir. Ancak literatür veriler (45) tek başına tırnak kesiminin DD'nin önlenmesi veya tedavisi için yetersiz olabileceğini düşündürmektedir. $\mathrm{Bu}$ çalışmalarda gözlemlenen DD enfeksiyonundaki azalmada, kimyasal ajanların etkisinin yanı sıra, tırnak kesimi ile tırnağın biçimsel özelliklerinde yapılan düzeltmeler özellikle de ökçe yüksekliğinin normal haline getirilmesinin etkili olduğu söylenebilir (15). Bu uygulama tırnağın ökçe ve bukağılık bölgesinin dışkı bulamacına maruz kalmasını azaltır; böylelikle, bölgeyi DD lezyonlarının kalıcılığı açısından elverişsiz hale getirir. Nitekim doğum öncesi tırnak kesimi yapılan düvelerin arka ayak dış tırnağında daha fazla modelleme yapmanın (taban-ökçe geçiş bölgesinde daha geniş konkavite oluşturulması), bu hayvanlarda doğum sonrası dijital dermatitis oluşumunu önemli ölçüde azalttığı bildirilmiştir. Yine fonksiyonel tırnak kesimi sırasında arka ayak iç tırnağın ökçelerini korumanın DD'nin önlenmesinde etkili olduğu bildirilmiştir (46). Fonksiyonel tırnak kesiminin son aşamasında ökçe bölgesindeki eroziv tırnak dokuları renet ucu ile kazınarak uzaklaştırılır (Şekil 4). Böylece ökçe bölgesinde oluşan yarık ve oyuklar giderilerek enfeksiyon etkenleri için uygun olan aneorobik ortam kaldırılmış olur (1).

Tırnak kesimini yapan kişilerin ve kullanılan alet ve ekipmanların inekler arasında DD bulaşmasını artırdığı gösterilmiştir $(47,48,49)$. Tırnak kesimi, potansiyel olarak enfekte olmuş ayak dokularına doğrudan temas söz konusu olduğu için, DD etkenlerinin sağlam dokuya kolayca ulaşması ve hastalığı başlatabilmesi açısından önemli bir mekanizma olabilir. Kontamine olmuş ekipmanlar inekten ineğe veya çiftlikler arası bulaşmada aracılık yapabileceğinden, DD'li ineklerde koruyucu ve terapötik tırnak kesimi yaparken dikkatli olunmalıdır. Bu kontaminasyon kısa aralıklarla tırnak kesimi yapılan sürülerde daha yüksek DD prevalansına ve aynı tırnak kesicisinin birden fazla çiftliğe hastalık bulaştırmasına neden olabilir $(44,49)$. Bu bağlamda, işletmelerde rutin tırnak kesimi ve ayak bakımının, işletmenin eğitilmiş kendi personelleri tarafından yapılması bulaşma riskini azaltacaktır. 


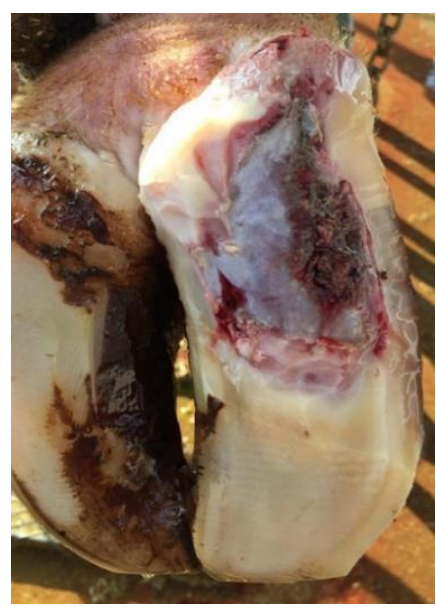

Şekil 2. Tabanda canlı doku ile ilişkis kesilmiş tüm tırnak dokusu uzaklaştırılır.

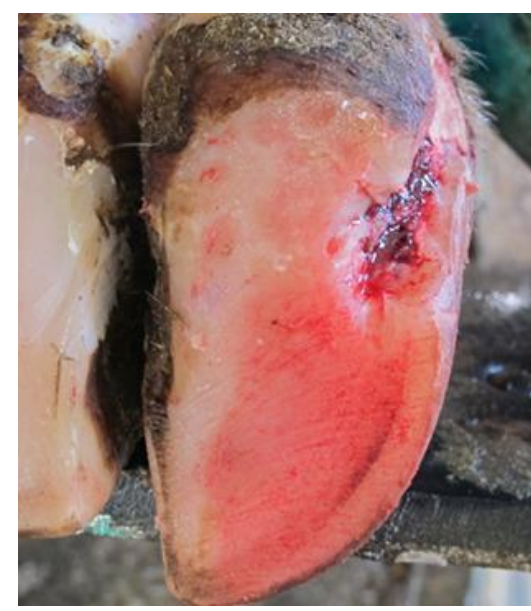

Şekil 3. Abaksiyal beyaz çizgi hastalığında lezyon bölgesinde lateral duvarın taban ve beyaz çizgi ile ilişkili kısmı uzaklaştırılır.

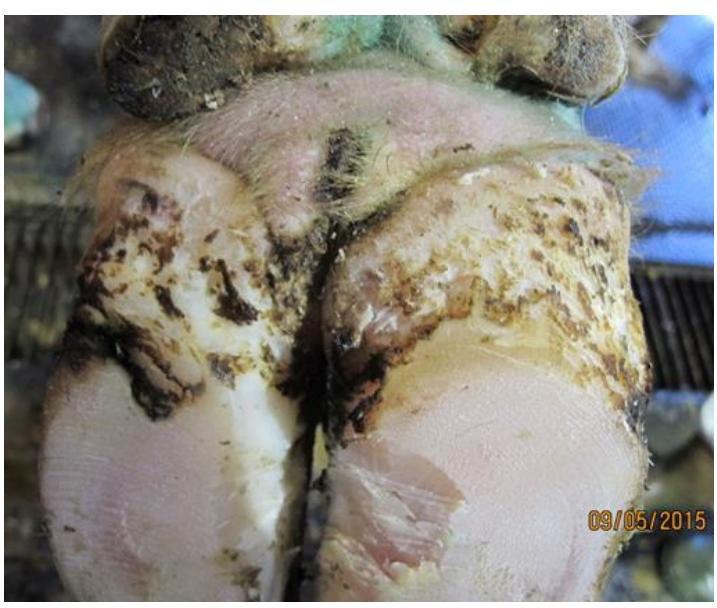

Şekil 4. Ökçe bölgesindeki eroziv tırnak dokularının uzaklaştırılması.

\section{Diğer Tırnak Lezyonları ve Tırnak Kesimi}

Süt sığırlarında BCTL ve enfeksiyöz ayak derisi lezyonlarının dışında en yaygın görülen lezyonlar interdijital hiperplazi, ince taban, tırnak çatlakları ve tirbüşon tırnak, makasvari tırnak gibi tırnak bozukluklarıdır. Bunlar arasında klinik pratikte hatalı tırnak kesimine bağlı olarak en yaygın görüleni ince taban lezyonlarıdır. Tabanın aşırı inceltilmesi ölçü klavuzu kullanmadan yapılan tırnak kesimlerinde en çok yapılan hatadır. Özellikle fleks kullanılarak yapılan tırnak kesimlerinde tabanın aşırı yontulması tabanın incelmesinin önemli sebeplerinden biridir. Tabandaki tırnak dokusunun aşırı kesilmesi, beyaz çizgi hastalığı, taban ucu ülseri ve nekrozunun en önemli nedenidir $(1,50)$.

Tırnak kesimi ile tırnak çatlakları, tirbüşon tırnak, makasvari tırnak, interdigital hiperplazi arasındaki ilişki hakkında çok az veri bulunmaktadır. Tirbüşon tırnak kalıtsal bir bozukluk olması nedeniyle oluşumunu engellemek mümkün değildir. Ancak düzenli fonksiyonel tırnak kesimi ile gelişimi engellenebilir. Terapötik tırnak kesiminin interdigital hiperplazi prevalansını düşürdüğü bildirilmiştir (51).

\section{Tırnak Kesimi Ne Zaman Yapılmalıdır?}

Tırnak kesiminin zamanı konusunda uygun şekilde tasarlanmış araştırmalara ihtiyaç vardır. Topallığa neden olan ayak hastalıklarının erken teşhis ve tedavisi, sağladığı fayda ve hastalığın prognozu bakımından önemlidir $(11,38,40)$. Koruyucu tırnak kesiminin önemli amaçlarından birisi de tırnak bozukluklarını ve ayak hastalıklarını önceden tespit etmek ve önlemektir $(1,10)$. Bir inek için topallık oluşma riskinin en yüksek olduğu dönem laktasyonun 2. ve 5 . ayları arasındaki dönemdir (2). Bu durum kuru döneme girmeden ya da kuru dönemin başında ve laktasyonun 3. ve 4. aylarında koruyucu tırnak kesimi yapmanın önemini göstermektedir. Nitekim kuru dönemden önce tırnak kesimi yapılan ineklerde topallık ihtimalinin daha düşük olduğu $(19,52)$ ileri sürülmüştür.

Laktasyonun erken dönemlerinde koruyucu tırnak kesimi yapılan çiftliklerde topallık seviyelerinin düştüğü ileri sürülmüştür (19). Laktasyon ortasında tırnak kesimi yapılan ineklerde kümülatif topallık insidansının kontrol grubuna kıyasla daha düşük olduğu bildirilmiştir (53). Laktasyonun sonunda veya kuru dönemden önce yapılan tırnak kesiminin, takip eden laktasyonun erken döneminde faydalı etkilerinin olması beklenir. Çok sayıda yapılan tırnak kesim sonuçlarının analiz edildiği bir çalışmada (32), kuru dönem öncesinde yapılan tırnak kesimini takip eden laktasyonda, daha düşük taban ülseri oluşumu bildirilmiştir.

Topallık teşhisinden sonra terapötik tırnak kesimi ne kadar kısa sürede yapılırsa iyileşme oranı o kadar yüksek olacaktır. Bu nedenle topallık skoru 2-3 olan inekler en geç 2 gün içinde, topallık skoru 4-5 olan inekler tespit edilir edilmez tedavi edilmelidir $(1,54)$. Topallığın belirlenmesinden 2 hafta sonra tırnak kesimi yapılan ineklerde iyileşme oranlarının düşük olduğu (\%15-16) gözlenmiştir (37).

\section{Tırnak Kesim Sıklığ}

Süt sığırlarında tırnak kesim sıklığı ve topallık oluşumu arasındaki ilişkiyi açıklayan literatür veri oldukça azdır. Genel bir kabul olarak yılda en az iki kez, ineklerin tırnakları değerlendirilmeli ve tırnak kesiminin gerekip gerekmediğine karar verilmelidir. Özellikle laktasyon sırasında koruyucu tırnak kesim ihtiyacı, çeşitli barınak sistemlerinde BCTL'ye neden olan diğer faktörlere bağlı olarak artar veya azalabilir. Genel olarak, birinci tırnak kesiminden yaklaşık 4-6 ay sonra ikinci tırnak kesimi için değerlendirme yapılmalıdır. Topal olan veya tırnakları uzayan tüm hayvanlarda mümkün olan en kısa sürede tırnak kesimi yapılmalıdır (1). Laktasyon sırasında iki kez koruyucu tırnak kesimi yapılan çiftliklerde bir kez tırnak kesimi yapılan çiftliklerden daha az BCTL görülmüştür (15).

\section{SONUÇ}

Süt sığırlarında tırnak kesimi topallıkların önlenmesinde önemli bir uygulamadır. Bu makale kapsamında yapılan literatür incelemesinde; tırnak kesiminin ayak ve tırnak sağlığının korunmasındaki gerçek rolünün belirlenmesi için ileri düzeyde çalışmalara ihtiyaç olduğu görülmüştür. Bu çalışmalarda tırnak kesim yöntemlerinin farklı barınak sistemlerindeki etkileri, tırnak kesiminin zamanlaması, sıklığı ve uzun vadeli koruyucu etkisinin araştırılması mevcut bilgi birikimine ve çiftliklerde topallık yönetim stratejisi oluşturma ve tırnak 
kesimine ilişkin karar alma konusunda çok önemli katkılar sağlayacaktır.

Düzenli ve doğru yapılan tırnak kesimi, ayak ve tırnak sağığının korunması ve topallıkların önlenmesi bakımından çok önemlidir. Hatalı tırnak kesimi dünyada ve ülkemizde süt sığırlarında topallığa neden olan en önemli faktörlerden birisidir. Eğitimli ve bilinçli bir tırnak kesicisi, tırnakta gelişmekte olan bir sorunu önceden görebilir ve sorun büyümeden çözümü yönünde erken adım atabilir. Aksi halde tırnak kesiminin kendisi; topallık oluşumunda önemli bir risk faktörü haline gelir. Maalesef ülkemizde sığırlarda tırnak kesimi, büyük oranda bu konuyla ilgili hiçbir eğitimi olmayan insanlar tarafından yapılmaktadır. Olası komplikasyonların önüne geçmek ve beklenen faydayı sağlamak adına tırnak kesimi mutlaka bu konuda eğitim almış (sertifikalı) profesyonel kişiler tarafından yapılmalıdır (55). Bu amaçla; işletme sahibi, çiftlik çalışanları ve tırnak kesimi yapan personelin belli aralıklarla bilgilendirme ve eğitim kurslarına tabi tutulmaları gerekmektedir.

Ayrıca ülkemizde; tırnak kesiminin mahiyeti ve sorumluluğuna ilişkin hiçbir hukuki dayanak yoktur. Bu bağlamda; gerek hayvan sağlığının korunması ve ekonomik kayıpların önlenmesi gerekse hayvan refahı bakımından konuya ilişkin bir mevzuat oluşturulmasının gerekliliği açıktır.

\section{KAYNAKLAR}

1. İzci C. (2018). Sığırlarda Ayak Hastalıkları ve Topallık Kontrolü. I. Baskı, Selçuk Üniversitesi Basımevi, Konya.

2. Green LE, Hedges VJ, Schukken YH, Blowey RW, Packington AJ. (2002). The Impact of Clinical Lameness on The Milk Yield of Dairy Cows. J Dairy Sci. 85: 2250-2256.

3. Archer SC, Green MJ, Huxley JN. (2010). Association between Milk Yield and Serial Locomotion Score Assessments in UK Dairy Cows. J Dairy Sci. 93: 4045-4053.

4. Huxley JN. (2013). Impact of Lameness and Claw Lesions in Cows on Health and Production. Livest Sci. 156: 64-70.

5. Garbarino EJ, Hernandez JA, Shearer JK, Risco CA, Thatcher WW. (2004). Effect of Lameness on Ovarian Activity in Postpartum Holstein Cows. J Dairy Sci. 87: 4123-4131.

6. Randall LV, Thomas HJ, Remnant JG, Bollard NJ, Huxley NJ. (2019). Lameness Prevalence in A Random Sample of UK Dairy Herds. Short Communication. Vet Rec. 16: 184, 11, 350.

7. Shearer J, Van Amstel S. (2013). Manual of Foot Care in Cattle. 2nd edition, W.D. Hoard and Sons Company, USA.

8. Shearer JK, Van Amstel SR. (2001). Functional and Corrective Claw Trimming. Vet Clin North Am Food Anim Pract. 17: 53-72.

9. Archer SC, Newsome R, Dibble H, et al. (2015). Claw Length Recommendations for Dairy Cow Foot Trimming. Vet Rec. 177(9): 222.

10. Raven ET. (1989). Cattle Footcare and Claw Trimming. Ipswich Farming Press, United Kingdom.

11. Thomas HJ, Miguel-Pacheco GG, Bollard NJ, et al. (2015). Evaluation of Treatments for Claw Horn Lesions in Dairy Cows in A Randomized Controlled Trial. J Dairy Sci. 98: 4477-4486.

12. Blowey RW. (2015). Cattle Lameness and Hoof Care. 3rd Edition, Sheffield, England.

13. Daniel V. (2014). Trimmers Tool Box: Working Diverse Methods and Options for Hoof Care into A Common Goal of Attaining Healthy Feet and Satisfied Clients. Missoula (MT): Hoof Trimmers Assoc Inc.
14. Siebert L. The Kansas Hoof Trimming Method. The National Association of Cattle Foot Trimmers (NACFT). Trimmer, December, 8-13. Erişim: http://www.nacft.co.uk/downloads/Trimmer-Dec-16.pdf. Erişim tarihi: 31.01.2021

15. Manske T, Hultgren J, Bergsten C. (2002). Prevalence and Interrelationships of Hoof Lesions and Lameness in Swedish Dairy Cows. Prev Vet Med. 54: 247-63.

16. Karvountzis S. Dairy Cow Hoofcare with The White Line Atlas Technique. Erişim: https://www.walesfarmer.co.uk/news/18716294. Erişim tarihi: 06.02.2021

17. Solano L, Barkema HW, Mason S, Pajor EA, LeBlanc SJ, Orsel K. (2016). Prevalence and Distribution of Foot Lesions in Dairy Cattle in Alberta, Canada. J Dairy Sci. 99: 6828-6841.

18. Stoddard GC, Cramer G. (2017). A Review of The Relationship between Hoof Trimming and Dairy Cattle Welfare. Vet Clin Food Anim Pract. 33: 365-375.

19. Griffiths BE, Grove White D, Oikonomou G. (2018). A Cross-Sectional Study into The Prevalence of Dairy Cattle Lameness and Associated Herd-Level Risk Factors in England and Wales. Front Vet Sci. 5: 65.

20. İzci C, Erol M, Gökşahin E. (2018). Boynuz ve Canlı Tırnak Lezyonu (BCTL) Bulunan Süt Sığırlarında Ökçe Yastığının Ultrasonografik Olarak Değerlendirilmesi. Eurasian J Vet Sci. 34(2): 109-16.

21. Sepuveda-Varas P, Lomb J, Von Keyserlingk MAG, Held R, Bustamante H, Tadich N. (2018). Claw Horn Lesions in Mid-Lactation Primiparous Dairy Cows Under Pasture-Based Systems: Association with Behavioral and Metabolic Changes Around Calving. J Dairy Sci. 101: 9439-9450.

22. Shearer JK, Van Amstel SR. (2017). Pathogenesis and Treatment of Sole Ulcers and White Line Disease. Vet Clin North Am Food Anim Pract. 33(2): 283-300.

23. Ossent $P$, Lischer CJ. (1998). Bovine Laminitis: The Lesions and Their Pathogenesis. In Pract. 20: 415-427.

24. Bicalho RC, Machado VS, Caixeta LS. (2009). Lameness in Dairy Cattle: A Debilitating Disease or A Disease of Debilitated Cattle A Cross-Sectional Study of Lameness Prevalence and Thickness of The Digital Cushion. J Dairy Sci. 92(7): 3175-3184.

25. Kumar A, Singh G. Feeding of Dam During Postpartum Period to Augment Fertility in Bovines: A Scientific Approach. Erişim: https://en.engormix.com/dairy-cattle/articles. Erişim tarihi: 01.12 .2020

26. İzci C, Erol M, Gökşahin E. (2011). A Study About Determining The Changes in The Structural Characteristics of The Digital Cushion in Heifer and Multipar Dairy Cows: A Preliminary Report. Kafkas Univ Vet Fak Derg. 17(1): 159-162.

27. İzci C, Erol M, Çelik i. (2014). Boynuz Tırnak Lezyonu Bulunan Düve ve Süt İneklerinde Ökçe Yastı̆̆ının Yapısal Özelliklerindeki Dönemsel Değişikliklerin Belirlenmesi. Tamamlanmış TÜBiTAK Projesi (1001), Proje No: 1120332.

28. Hiss-Pesch S, Weise J, Heitkönig B, Sauerwein H. (2019). Short Communication: Adipocyte Sizes in The Digital Fat Pad and Their Relationship to Body Condition in Dairy Cows. J Dairy Sci. 102:6551-4.

29. İzci C, Çelik I, Erol M, Gökşahin E. (2019). Histochemical and Histomorphometrical Studies on The Digital Cushion of Heifers and Dairy Cows with Claw Horn Lesions. Con Dai \& Vet Sci. 2(5): 254-61.

30. Akköse M, İzci C. (2017). Süt İneklerinde Yatma Süresinin Topallıklara Etkisi ve Yatma Süresini Etkileyen Faktörler. Lalahan Hay Araşt Enst Derg. 57(1): 44-51.

31. Griffiths BE, Mahen PJ, Hall R, et al. (2020). A Prospective Cohort Study on The Development of Claw Horn Disruption 
Lesions in Dairy Cattle; Furthering Our Understanding of The Role of The Digital Cushion. Front Vet Sci. 7: 440.

32. Thomsen PT, Foldager L, Raundal P, Capion N. (2019). Lower Odds of Sole Ulcers in The Following Lactation in Dairy Cows that Received Hoof Trimming Around Drying Off. Vet J. 254: 105408

33. Kofler J. (1999). Clinical Study of Toe Ulcer and Necrosis of The Apex of The Distal Phalanx in 53 Cattle. Vet J. 157(2): 139-147.

34. Leach KA, Tisdall DA, Bell NJ, Main DCJ, Green LE. (2012). The Effects of Early Treatment for Hindlimb Lameness in Dairy Cows on Four Commercial UK Farms. Vet J. 193: 626-632.

35. Thorup VM, Do Nascimento OF, Skjoth F, et al. (2014). Short Communication: Changes in Gait Symmetry in Healthy and Lame Dairy Cows Based on 3-Dimensional Ground Reaction Force Curves Following Claw Trimming. J Dairy Sci. 97: 76797684.

36. Coetzee JF, Shearer JK, Stock ML, Kleinhenz MD, Van Amstel SR. (2017). An Update on The Assessment and Management of Pain Associated with Lameness in Cattle. Vet Clin Food Anim Pract. 33(2): 389-411.

37. Thomas HJ, Remnant JG, Bollard NJ, et al. (2016). Recovery of Chronically Lame Dairy Cows Following Treatment for Claw Horn Lesions: A Randomised Controlled Trial. Vet Rec. 178(5): 116.

38. Passos LT, Cruz EA, Fischer V, et al. (2017). Dairy Cows Change Locomotion Score and Sensitivity to Pain with Trimming and Infectious or Non-Infectious Lesions. Trop Anim Health Prod. 49: 851-856.

39. İzci C. (2013). Tırnak Kesimi Nasıl Yapııır? Sığırlarda Topallık ve Ayak Hastalıkları Sempozyumu, 26-27 Nisan, Kervansaray Termal Otel, Bursa.

40. Miguel-Pacheco GG, Thomas HJ, Huxley JN, Newsome RF, Kaler J. (2017). Effect of Claw Horn Lesion Type and Severity at The Time of Treatment on Outcome of Lameness in Dairy Cows. Vet J. 225: 16-22.

41. Bell NJ, Bell MJ, Knowles TG, Whay HR, Main DCJ, Webster AJF. (2009). The Development, Implementation and Testing of A Lameness Control Programme Based on HACCP Principles and Designed for Heifers on Dairy Farms. Vet J. 180: 178-188.

42. Wells SJ, Garber LP, Wagner BA. (1999). Papillomatous Digital Dermatitis and Associated Risk Factors in US Dairy Herds. Prev Vet Med. 38: 11-24.
43. Somers J, Frankena K, Noordhuizen-Stassen EN, Metz JHM. (2005). Risk Factors for Digital Dermatitis in Dairy Cows Kept in Cubicle Houses in The Netherlands. Prev Vet Med. 71: 11-21.

44. Holzhauer M, Hardenberg C, Bartels CJM, Frankena K. (2006). Herd and Cow Level Prevalence of Digital Dermatitis in The Netherlands and Associated Risk Factors. J Dairy Sci. 89: 580-588.

45. Yamamoto T, Manabe H, Okada K. (2018). Combination Effect of Allyl Isothiocyanate and Hoof Trimming on Bovine Digital Dermatitis. J Vet Med Sci. 80: 1080-1085.

46. Burgi K. The Fundamentals for Good Hoof Health, Dairyland Hoof Care Institute, Inc. Erişim: https://www.wiagribusiness.org/fourstatedairy. Erişim tarihi: 22.0220121

47. Yang DA, Laven RA, Heuer C, Vink WD, Chesterton RN. (2018). Farm Level Risk Factors for Bovine Digital Dermatitis in Taranaki, New Zealand: An Analysis Using A Bayesian Hurdle Model. Vet J. 234: 91-5.

48. Gillespie A, Evans N. (2020). Infection Reservoirs and Transmission of Digital Dermatitis in The Dairy Herd. Livestock. 25(3): 118-124.

49. Sullivan LE, Blowey RW, Carter SD, et al. (2014). Presence of Digital Dermatitis Treponemes on Cattle and Sheep Hoof Trimming Equipment. Vet Rec. 175:201.

50. Kofler J. (2017). Pathogenesis and Treatment of Toe Lesions in Cattle Including "Nonhealing" Toe Lesions. Vet Clin Food Anim Pract. 33: 301-328.

51. Schulz T, Gundelach Y, Feldman M, Hoedmaker M. (2016). Early Detection and Treatment of Lame Cows. Tierarztl Prax. 44: 511.

52. Daros RR, Eriksson HK, Weary DM, Von Keyserlingk MAG. (2019). Lameness During The Dry Period: Epidemiology and Associated Factors. J Dairy Sci. 102: 11414-11427.

53. Gomez A, Cook NB, Rieman J, et al. (2015). The Effect of Digital Dermatitis on Hoof Conformation. J Dairy Sci. 98: 927-936.

54. Huxley J, Archer S, Bell N, et al. (2012). Control of Lameness. In Dairy Herd Health Edited by Martin Green. 169-204.

55. FAWC (1993). Report on Priorities for Animal Welfare: Research and Development. Farm Animal Welfare Council, London, 4-14.

\section{Sorumlu Yazar:}

Kadir SULU

Selçuk Üniversitesi Veteriner Fakültesi Cerrahi AnabilimDalı, Konya TÜRKIYE

E-posta: kadirsulu24@gmail.com 